\title{
Institutional Quality and the Public Investment-Growth Relationship in Vietnam
}

\author{
Nguyen Van Bon \\ Faculty of Finance \& Accounting, Sai Gon University (SGU), Ho Chi Minh City, Vietnam \\ Email: bonvnguyen@yahoo.com, boninguyen@gmail.com
}

How to cite this paper: Van Bon, N. (2019) Institutional Quality and the Public Investment-Growth Relationship in Vietnam. Theoretical Economics Letters, 9, 691708.

https://doi.org/10.4236/tel.2019.94046

Received: February 15, 2019

Accepted: March 26, 2019

Published: March 29, 2019

Copyright ( 2019 by author(s) and Scientific Research Publishing Inc. This work is licensed under the Creative Commons Attribution International License (CC BY 4.0).

http://creativecommons.org/licenses/by/4.0/

\section{(c) (i) Open Access}

\begin{abstract}
Questions concerning the relationship between public capital spending and economic growth under different institutional environments are of great analytical and empirical interest. This paper investigates the role of institutional quality in the public investment-growth relationship for a balanced panel data of 52 provinces in Vietnam during the period 2005-2014 through the estimation method of difference panel GMM Arellano-Bond. The results show twofold. First, public investment and institutional quality significantly promote economic growth, but their interaction term impedes it. Second, the public investment-growth relationship is positive under good institutional environment and negative under poor one. These findings suggest some important policy implications related to public capital spending in developing countries.
\end{abstract}

\section{Keywords}

Public Investment, Institutional Quality, Economic Growth, Difference Panel GMM, Provinces of Vietnam

\section{Introduction}

Most of governments worldwide increasingly invest in infrastructure, education, and health through public investment projects to actively foster economic growth, create more employments, and stabilize social security. Thus, public investment is not only an instrument of fiscal policy that helps governments run the economy but also one of crucial factors contributing to economic growth. However, public capital spending may be detrimental to economic development, which originates from two main causes: 1) public capital spending reduces private investment due to crowding-out effect, and 2) inefficient public investment projects do not bring the expected benefits to people, and lower the productivity 
of public capital. In this context, the institutional environment in a country plays an important role. Good institutional environment not only reduces the crowding-out effect of public sector on private sector but also improves the quality and efficiency of public investment projects and positively contributes to economic activities.

Given the relevance of this topic, there is a deeply consensus among economists and politicians that public capital spending in infrastructure is a crucial factor of a competitive location policy. Infrastructure may lower fixed costs, attracting enterprises and factors of production and, thereby, raising production [1] [2]. Indeed, public investment can stimulate private investment by providing infrastructure for economic activities. Thus, it leads to raise the productivity of capital and promotes economic growth. However public investment can crowd out private investment. It occurs when additional public investment capital is financed by high future taxes and high interest rates, or public sector produces goods that directly compete with private goods. Moreover, the utilization of physical capital and financial resources of public sector, which is conventionally a priority access for private sector, may reduce the investment capital of private sector [3]. The crowding-out impact may occur when the distortion of public sector is too large. To finance for increasing public investment, the government needs more physical capital, which leads to high interest rates; thus, it reduces private sector's ability to access the capital markets. As a result, economic growth goes down due to the decline in private sector's investment.

However, the effect of public investment on economic growth may be conditional on institutional quality, for example the control of corruption, in the country. [4] have developed a theoretical growth model to show the influence of corruption on the relationship between public investment and economic growth. In this model, public officials are responsible for procuring public goods and equipment that are used as productive inputs in the production. Due to the information asymmetry between the government and public officials, public officials may deceitfully make a report of high-quality high-cost procurement, while supplying low-quality low-cost products. So, corruption inflates the level of capital on public investment projects, but reduces the returns to that capital; in this case because either they go nowhere or they are of low quality. Both channels may lead to reduce economic growth.

Meanwhile, [5] argue that corruption may distort the whole decision-making process associated with the government investment budget. The "white elephants" and "cathedrals in the desert" phenomena in public investment projects are produced. Some projects are accomplished but in reality never used. Some are larger and more complex than necessary whereas their quality is so low that they need to be repaired before exploiting. Noticeably, their output capacity is much below initial expectations. In these situations, public capital spending becomes much less productive and its contribution to economic growth is much less than generally believed. 
Conversely, under a good institutional environment the public sector may undertake low profit, large capital projects which the private sector refuses and leave other projects which the private sector can do better. In addition, public investment projects are strictly supervised and monitored by both the government and people to ensure the efficiency and transparency. Therefore, under the good institutional environment, public investment can crowd-in private investment and improve the productivity of public capital spending, which lead to boost economic growth.

In Vietnam, public capital spending is a primary derivative of infrastructure development for the economy. During the transition process to a market-oriented economy, the Vietnam government continuously implements the expansionary fiscal policy by increasing public capital spending with expectation that public investment has positive effects on economic activities, enhances the productivity of the economy, and stimulates investment capital from private sector. However, the level of public investment capital of the Vietnam government often fluctuates, which strongly depends on the situation of the economy. In the case of economic recession and high unemployment, the level of public investment capital increases very high; but it will be cut down immediately if the economy grows rapidly with high inflation. In recent years, by perceiving the comments and ideas of economic experts and economists, the Vietnam government regularly reforms policies and improves the institutional environment to make sure the public capital spending is more efficient and transparent. Consequently, it enhances the participation of private sector in the key projects of the State such as highway building projects, public private partnership (PPP) projects in infrastructure sector and healthcare...

Motivated by the fact Vietnam is an economy with a relatively high level of public investment that can have a significant impact on growth, we shed a new light on the importance of taking institutional quality into account for the understanding of public investment-growth relationship in Vietnam. Most of the related literature on public investment has either examined the relationship between public investment and economic growth [6] [7] [8] or the relationship between institutions and public investment [9] [10]. So far, there are just a few investigations on the role of institutions in the public investment-growth relationship [4] [11]. In particular, no existing papers estimate the public investmentgrowth relationship under different institutional environments. To investigate the importance of institutional quality in the public investment-growth relationship in Vietnam, we first use the two step difference GMM Arellano-Bond estimator (two step D-GMM) to estimate the effects of public investment, institutional quality and their interaction term on economic growth for a balanced panel data of 52 provinces over the period 2005-2014. Then, we examine the public investment-growth relationship under different institutional environments (good and poor institutional environment). In particular, the robustness of the estimation will be checked by the one step difference GMM Arellano-Bond estimator (one step D-GMM). 
The remainder of this paper will be proceeded as follows: Section 2 outlines a literature review about the effect of public investment on economic growth. Section 3 develops an analytical framework to form the empirical equations. Section 4 describes the model specification and data. Section 5 presents the results and discussion, and final section is the conclusion and policy implications.

\section{Literature Review}

Public capital plays a crucial role in economic development because it contributes to improving infrastructure and enhancing accumulation of human capital. [12] show public capital investment has a significantly positive net impact on national product in Pakistan over the period 1964-1997 by using OLS estimation. Meanwhile, [13] argue that public capital is a critical input of production and positively promotes economic activities of private sector while the way public sector being financed can be detrimental to this sector's development. Indeed, by employing VAR model for quarterly time series data of six developed countries, [13] approve public investment is a source of endogenous growth. Similarly, [14] use the extension Solow-Swan growth model developed by Mankiw, Romer and Weil for 74 countries and find the effect of public investment on economic growth is no significant for the steady state model while it is significantly positive for the transition model.In the same vein, by using 3SLS estimation and time series data during 1981-2003, [15] show a sustained increase in public capital spending in infrastructure in India, financed by commercial banks, positively affects economic growth. More recently, [8] employ ADL estimations proposed by Krolzig-Hendry-Doornik to investigate the effect of public investment on Portuguese economic growth over the period 1960-2013. The estimated results show public investment has a significantly positive effect on economic growth.

However, government decisions on the distribution of public capital among regions are of great political concern among policymakers [16]. [17] suggest scarce public sources should be used for contribution to new human capital (via education) and the maintenance of existing human capital (through healthcare). Using the seemingly unrelated (SUR) procedure for nine major Latin American countries during the period 1983-1993, [17] show public investment spending positively contributes to economic growth. [16], who employs fixed effects estimation for a panel data of 47 prefectures in Japan during the period 1955-2000, concludes public investment is a policy tool for adjusting income distribution and boosting economic growth in regions. In addition, policies of fiscal adjustment towards decreasing government investment may reduce aggregate investment, negatively affect economic growth and even impede the adjustment in the future [18]. The paper by [18] which uses VECM model for seven highly indebted low-income countries over the period 1970-1999 finds a significantly positive relation between public investment and output in these countries.

In addition, some models are developed to examine the effect of public capital spending on economic growth. [6] develop a model which captures not just the 
effect of public capital spending in Greek prefectures, but also the spillovers associated with the existence of externalities from neighboring regions. The results from testing this model by the estimation methods of fixed effects and pooled OLS for a panel data of 51 prefectures in Greek during the period 1978-2007 show a significantly positive effect of public investment on regional economic growth in long run. In the same way, [7] use model simulations to investigate the macroeconomic effects of public investment for a sample of 17 OECD economies over the period 1985-2013. The study finds increased public investment promotes economic growth in both short term and long term, crowds in private investment, and reduces unemployment.

So far, however, there just exist a few papers to investigate the role of institutional quality in the relationship between public investment and economic growth. According to [11], corruption may prevent poor countries from catching up with richer ones. However, the influence of corruption is not always the same. It may distort the allocation of public expenditure. The type of distortion depends on the extent to which political power is concentrated in the hands of rent-seekers. In order to prove this argument, De la Croix and Delavallade use a two-stage least squares estimation for a sample of 62 countries over the period 1996-2004. The empirical results show the influence of a poor legal system on the structure of public capital investment depends on the level of development. When corruption is made possible by a failing legal system, public expenditure is distorted in favor of human capital spending in order to discourage rent-seekers from corruption in richer countries while a fall in the ratio of human capital to physical capital spending in poor countries. Meanwhile, an endogenous growth model with information asymmetry between the government and the bureaucracy is developed by [4] to explain why public capital investment fails to raise economic growth in the countries where corruption is endemic. To demonstrate this idea, Haque and Kneller use three-stage least squares method for a sample of 66 countries from 1970 to 2000 . The empirical results show corruption increases public investment and corruption reduces the returns to public investment and makes it ineffective in raising economic growth.

\section{Analytical Framework}

Supposing the economy has two major inputs including domestic capital stock (public and private investment capital) and working force. The analytical framework starts with the traditional aggregate production function Cobb-Douglas as follows:

$$
Y=A G^{\alpha} P^{\beta} L^{1-\alpha-\beta}, 0<\alpha<1
$$

where $Y$ is real gross domestic product (GDP); $G$ and $P$ are public investment capital and private investment capital respectively; $L$ is the number of workers

employed; $A$ is the total factor productivity (TFP); $\alpha, \beta$, and $1-\alpha-\beta$ are the production elasticities.

We transfer Equation (1) into the log-linear form: 


$$
\log Y=\log A+\alpha \log G+\beta \log P+(1-\alpha-\beta) \log L
$$

We write Equation (2) in growth form with a time series specification:

$$
Y_{i, t}=A_{i, t}+\alpha G_{i, t}+\beta P_{i, t}+(1-\alpha-\beta) L_{i, t}
$$

According to the theory of endogenous growth [19] [20], the total factor productivity, capital stock and working force are endogenous variables. For convenience Equation (3) is rewritten as follows:

$$
Y_{i, t}=A_{i, t}+\alpha_{1} G I N V_{i, t}+\alpha_{2} P I N V_{i, t}+\alpha_{3} L A B O_{i, t}
$$

Where GINV, PINV, and $L A B O$ are public investment, private investment, and labor force respectively. Public investment has a positive impact on economic growth because it contributes to improving infrastructure and enhancing accumulation of human capital. [21] confirm that the government plays a crucial role in accumulation of human capital by public spending in education. Thus, public investment affects the long-run economic growth.

There are many factors which have impacts on the total factor productivity (TFP). In this study, the determinants of TFP are determined as follows:

$$
A_{i, t}=\beta_{0}+\beta_{1} I N S_{i, t}+\beta_{2} G E X P_{i, t}+\beta_{3} O P E N_{i, t}+\beta_{4} C P I_{i, t}+\beta_{5} T E L E_{i, t}+\varepsilon_{i, t}
$$

where INS, GEXP, OPEN, CPI, TELE are institutional quality, recurrent expenditure, trade openness, consumer price index, and infrastructure development, respectively. Institutional quality has positive impacts on economic growth [22] [23] [24]. [25] analyse and develop a theoretical framework to clearly define the role of institutions in economic growth and outcomes in countries. Meanwhile, the composition of recurrent expenditure is diversified, including expenses for administration and costs of operations and maintenance for education, science, and technology. [26] argue in the growth theory that education, science, technology, environment, and healthcare are important factors for the economic prosperity in future. In the same vein, the theory of endogenous growth indicates the improved activities of imports and exports have a positive impact on economic growth [19] [20]. The trade liberalization leads to highly absorb technological progress and exchange more imported goods and services between countries and so promotes the economic growth [27] [28]. In parallel, the consumer price index has important effects on growth [29]. Its impact on economic growth may be positive or negative. The positive impact comes from potential benefits of this index in improving the saving and investment while the negative impact is detrimental to the economy because it increases the transaction costs of economic activities [30]. Finally, the infrastructure development can be measured in some different ways such as the length of high way per square kilometer [31], the length of railway [32] or the fixed telephone subscriptions per 100 people [33]. It is proxy for development of infrastructure which has an influence on economic growth in a country [34].

We substitute Equation (5) into Equation (4):

$$
\begin{aligned}
Y_{i, t}= & \beta_{0}+\beta_{1} G I N V_{i, t}+\beta_{2} I N S_{i, t}+\beta_{3} P_{I N V_{i, t}}+\beta_{4} G E X P_{i, t}+\beta_{5} L A B O_{i, t} \\
& +\beta_{6} \operatorname{OPEN}_{i, t}+\beta_{7} C P I_{i, t}+\beta_{8} T_{E L E_{i, t}}+\varepsilon_{i, t}
\end{aligned}
$$


According to [35] [36], due to the conditional convergence of per capita income in the long term between the countries, the initial level of per capita income (the first lag of GDP per capita) has a negative impact on economic growth. In addition, in order to assess the effect of the interaction term between government investment and institutional quality, we add this variable (GINV * $I N S$ ) in the model. Therefore, the final empirical model is determined as follows:

$$
\begin{aligned}
Y_{i, t}-Y_{i, t-1}= & \beta_{0}+\beta_{1} Y_{i, t-1}+\beta_{2} G I N V_{i, t}+\beta_{3} I N S_{i, t}+\beta_{4} G I N V_{i, t} \times P C I_{i, t} \\
& +\beta_{5} P I N V_{i, t}+\beta_{6} G E X P_{i, t}+\beta_{7} L A B O_{i, t}+\beta_{8} O P E N_{i, t} \\
& +\beta_{9} C P I_{i, t}+\beta_{10} T E L E_{i, t}+\eta_{i}+\xi_{i, t}
\end{aligned}
$$

where $\varepsilon_{i t}=\eta_{i}+\xi_{i, t}$.

\section{Model Specification and Data}

\subsection{Model Specification}

Based on the analytic framework, the empirical equation is as follows:

$$
\begin{aligned}
Y_{i, t}-Y_{i, t-1}= & \beta_{0}+\beta_{1} Y_{i, t-1}+\beta_{2} G I N V_{i, t}+\beta_{3} P C I_{i, t} \\
& +\beta_{4} G I N V_{i, t} \times P C I_{i, t}+X_{i t} \beta_{5}^{\prime}+\eta_{i}+\xi_{i, t}
\end{aligned}
$$

or

$$
\begin{aligned}
Y_{i, t}= & \beta_{0}+\left(1+\beta_{1}\right) Y_{i, t-1}+\beta_{2} G I N V_{i, t}+\beta_{3} P C I_{i, t} \\
& +\beta_{4} G I N V_{i, t} \times P C I_{i, t}+X_{i t} \beta_{5}^{\prime}+\eta_{i}+\xi_{i, t}
\end{aligned}
$$

where subscript $i$ and $t$ are the province and time index, respectively. $Y_{i t}$ is natural logarithm of real GDP per capita in a province, $Y_{i t-1}$ is proxy for initial level of per capita income, $G I N V_{i t}$ is public investment, and $P C I_{i t}$ is the provincial competitiveness index, proxy for institutional quality in Vietnam. $X_{i t}$ is a set of control variables (private investment, recurrent expenditure, labor force, trade openness, infrastructure, and consumer price index); $\eta_{i}$ is an unobserved timeinvariant, province-specific effect and $\zeta_{i t}$ is an observation-specific error term. The coefficient $\beta_{1}$ in Equation (8) will be negative if it is conditional convergent and positive if divergent [34] [35].

For Equation (9), we use the general method of moments (GMM) Arellano-Bond estimators [37] first proposed by [38]. Equation (9) is a dynamic model, so we take the first difference to remove province-specific effects. Then, the regressors in first difference are used as instrumented by their lags under the assumption that time-varying disturbances in the original models are not serially correlated [39]. This strategy is D-GMM, which is well-known to be able to deal with simultaneity biases in regressions.

Equation (9) can be transformed into an equation in first difference as follows:

$$
\begin{aligned}
Y_{i t}-Y_{i t-1}= & \left(1+\beta_{1}\right)\left(Y_{i t-1}-Y_{i t-2}\right)+\beta_{2}\left(G I N V_{i t}-G I N V_{i t-1}\right) \\
& +\beta_{3}\left(P C I_{i t}-P C I_{i t-1}\right)+\beta_{4}\left(G I N V_{i t} \times P C I_{i t}-G I N V_{i t-1} \times P C I_{i t-1}\right) \\
& +\left(X_{i t}-X_{i t-1}\right) \beta_{5}^{\prime}+\left(\xi_{i t}-\xi_{i t-1}\right)
\end{aligned}
$$

In comparison with the one step D-GMM, the two step D-GMM is more 
asymptotically efficient. However, the application of the two step D-GMM in small samples, as in our study, has some problems [40]. These problems are set up by the proliferation of instruments, which quadratically increase as the time dimension increases. It can cause the number of instruments to be very large relative to the number of provinces. To avoid it, the rule of thumb should be applied to maintain the number of instruments less than or equal to the number of panel units [40].

The validity of instruments in D-GMM is assessed through Sargan statistic, Hansen statistic and Arellano-Bond statistic. The Sargan and Hansen tests with null hypothesis $\mathrm{H}_{0}$ : the instrument is strictly exogenous, which means that it does not correlate with errors. Thus, the p-value of Sargan statistic and Hansen statistic is as big as possible. The Arellano-Bond test is used to detect the autocorrelation of errors in first difference. Thus, the test result of first autocorrelation of errors, AR (1) is ignored while the second autocorrelation of errors, AR (2), is tested on the first difference series of errors to detect the phenomenon of first autocorrelation of errors, AR (1).

To examine the public investment-growth relationship under different institutional environment (good/poor), we determine a boundary value of institutional quality $(\gamma)$ and follow the empirical equations:

$$
\begin{gathered}
Y_{i t}=\theta_{10}+\theta_{11} Y_{i t-1}+\theta_{12} G I N V_{i t} \times d\left(P C I_{i t} \geq \gamma\right)+X_{i t} \theta_{13}^{\prime}+\eta_{i}+\xi_{i t} \\
Y_{i t}=\theta_{20}+\theta_{21} Y_{i t-1}+\theta_{22} G I N V_{i t} \times d\left(P C I_{i t}<\gamma\right)+X_{i t} \theta_{23}^{\prime}+\eta_{i}+\xi_{i t}
\end{gathered}
$$

In Equation (11) and Equation (12) $\gamma$ is the bound value of PCI (threshold value), and $d($.$) presents the indicator function, taking 1$ or 0 upon the value of PCI. The PCI index is constructed in a three-step sequence, referred to as the 3 Cs' [41]: 1) collect business survey data and published data sources, 2) calculate ten sub-indices and standardize to a 10-point scale, and 3) calibrate the composite PCI as the weighted mean of ten sub-indices with a maximum score of 100 points. Based on the composite PCI points, the institutional quality is categorized into 5 kinds: excellence (PCI $\geq 62$ points), high (60 - 62), mid-high (57 62 ), mid-low (56 - 57), low (53.5 - 56) and very low (PCI < 53.5). In this paper excellence, high and mid-high are coded into good institutions (PCI $\geq 57$ ) while mid-low, low and very low are coded into poor institutions $(\mathrm{PCI}<57)$. Thus, the boundary value of PCI is $\gamma=57$ points. This boundary value divides whole observations of the research sample into the group of good institutional environment with PCI greater than or equal 57 points and the group of poor one with PCI less than 57 points.

\subsection{Data}

Cross-sections and time series are extracted to accommodate the balanced panel data of 52 provinces over period of 2005-2014 from General Statistics Office of Vietnam (GSO). There are 11 out of 63 provinces eliminated due to data not available. We define and calculate the variables as follows: 
- Real GDP per capita (GDP): a real gross domestic product of a province, proxy for economic growth of a province. This variable is used in form of natural logarithm.

- Government investment (GINV): public investment capital in a province (\% GDP).

- Provincial competitiveness index (PCI): data on the institutional quality are obtained from the Vietnam Provincial Competitiveness Index survey, which are jointly carried out by United States Agency for International Development and the Vietnam Chamber of Commerce and Industry for the Vietnam Competitiveness Initiative, to assess and rank provincial governments by their regulatory environments for private sector development. This index is used as a governance index or institutional quality in Vietnam [42] [43] [44] [45] [46].

- Private investment (PINV): private investment capital in a province (\% GDP).

- Recurrent expenditure (GEXP): the current expenditure of a province (\% GDP).

- Labor force (LABO): a ratio between working age people (15 - 64) and total population of a province (\%).

- Trade openness (OPEN): a ratio between sum of exports and imports and GDP (\%). It is proxy for the policy of openness of a province.

- Consumer price index (CPI): a proxy for inflation of a province. It is used in form of natural logarithm.

- Infrastructure (TELE): the number of telephone lines per 100 people. It is proxy for development of infrastructure in a province. It is used in form of natural logarithm.

The statistical description of all data from General Statistics Office of Vietnam (GSO) is presented in the Table 1 .

The matrix of correlation coefficients between variables is given in Table 2 . All correlation coefficients between independent variables and dependent variable are statistically significant at least 5\%. Institutional quality, trade openness, and infrastructure are positively correlated with economic growth whilst public investment, private investment, recurrent expenditure, labor force, and consumer price index are negatively associated with it. In addition, the value of all correlation coefficients between independent variables is lower than 0.8 , which helps to eliminate the possibility of co-linearity between these variables.

\section{Empirical Results and Discussion}

\subsection{The Two Step D-GMM Estimates}

The estimated results derived from the two step D-GMM are shown in Table 3. Column 1 and Column 2 are respectively the reduced models without one/two variable(s) whilst Column 3 is the full model. To check the reliability of the sign and significance of estimated coefficients, some variables are removed out of the 
Table 1. Statistical description.

\begin{tabular}{cccccc}
\hline Variables & Obs & Mean & Std. Dev. & Min & Max \\
\hline Real GDP per capita (GDP) & 520 & 25.329 & 31.962 & 7.262 & 298.691 \\
Government investment (GINV) & 520 & 6.446 & 4.488 & 0.831 & 27.274 \\
Institutional quality (PCI) & 520 & 57.236 & 6.287 & 37.96 & 77.2 \\
Private investment (PINV) & 520 & 23.111 & 9.586 & 0.731 & 72.830 \\
Recurrent expenditure (GEXP) & 520 & 12.379 & 6.983 & 1.021 & 51.583 \\
Labor force (LABO) & 520 & 55.765 & 4.890 & 36.621 & 67.396 \\
Trade openness (OPEN) & 520 & 87.820 & 117.983 & 1.052 & 894.168 \\
Consumer price index (CPI) & 520 & 110.462 & 6.325 & 99.2 & 140 \\
Infrastructure (TELE) & 520 & 1816.343 & 8401.272 & 29.6 & 85215 \\
\hline
\end{tabular}

Source: State software.

Table 2. Matrix of correlation coefficients.

\begin{tabular}{|c|c|c|c|c|c|c|c|c|c|}
\hline & GDP & GINV & PCI & PINV & GEXP & LABO & OPEN & CPI & TELE \\
\hline GDP & 1.00 & & & & & & & & \\
\hline GINV & $-0.349^{\star * *}$ & 1.00 & & & & & & & \\
\hline PCI & $0.388^{* * *}$ & -0.025 & 1.00 & & & & & & \\
\hline PINV & $-0.251^{* * *}$ & $0.204^{* * *}$ & -0.032 & 1.00 & & & & & \\
\hline GEXP & $-0.588^{\star * *}$ & $0.546^{* * *}$ & $-0.332^{* * *}$ & $0.152^{\star * *}$ & 1.00 & & & & \\
\hline LABO & $-0.096^{\star *}$ & $-0.169^{* * *}$ & 0.009 & $0.117^{\star * *}$ & $0.262^{* * *}$ & 1.00 & & & \\
\hline OPEN & $0.415^{\star * *}$ & $-0.175^{\star * *}$ & $0.307^{\star * *}$ & -0.053 & $-0.345^{\star * *}$ & $0.091^{* *}$ & 1.00 & & \\
\hline CPI & $-0.116^{\star * *}$ & $0.082^{*}$ & $-0.102^{\star *}$ & 0.047 & 0.037 & -0.040 & -0.025 & 1.00 & \\
\hline TELE & $0.541^{\star * *}$ & $-0.214^{\star * *}$ & $0.289^{\star * *}$ & 0.022 & $-0.282^{\star * *}$ & $0.131^{\star * *}$ & $0.243^{\star * *}$ & 0.011 & 1.00 \\
\hline
\end{tabular}

Note: ${ }^{\star * \star},{ }^{\star *}$ and ${ }^{\star}$ denote significance at $1 \%, 5 \%$ and $10 \%$ respectively; Source: State software.

Table 3. Public investment, institutional quality and growth: D-GMM, 2005-2014. Dependent variable: $\Delta$ Real GDP per capita.

\begin{tabular}{|c|c|c|c|c|c|c|}
\hline \multirow{2}{*}{ Variables } & \multicolumn{3}{|c|}{ Two-step D-GMM } & \multicolumn{3}{|c|}{ One-step D-GMM } \\
\hline & (1) & (2) & (3) & (1) & (2) & (3) \\
\hline $\begin{array}{c}\text { Real GDP } \\
\text { per capita }(-1)\end{array}$ & $\begin{array}{c}-0.872^{\star * *} \\
(0.110)\end{array}$ & $\begin{array}{c}-0.910^{* * *} \\
(0.130)\end{array}$ & $\begin{array}{c}-0.934^{\star * *} \\
(0.131)\end{array}$ & $\begin{array}{c}-0.900^{\star * *} \\
(0.161)\end{array}$ & $\begin{array}{c}-0.938^{\star * *} \\
(0.203)\end{array}$ & $\begin{array}{c}-0.960^{* * *} \\
(0.178)\end{array}$ \\
\hline Public investment & $\begin{array}{l}64.957^{\star * *} \\
(17.764)\end{array}$ & $\begin{array}{l}63.713^{* * *} \\
(20.441)\end{array}$ & $\begin{array}{l}54.246^{* * *} \\
(17.142)\end{array}$ & $\begin{array}{l}55.774^{\star *} \\
(23.231)\end{array}$ & $\begin{array}{l}62.040^{* *} \\
(29.405)\end{array}$ & $\begin{array}{l}50.068^{\star *} \\
(22.173)\end{array}$ \\
\hline Institutional quality & $\begin{array}{l}6.948^{\star * *} \\
(1.960)\end{array}$ & $\begin{array}{l}6.876^{\star * *} \\
(2.297)\end{array}$ & $\begin{array}{l}5.127^{\star \star *} \\
(1.704)\end{array}$ & $\begin{array}{l}5.848^{* *} \\
(2.549)\end{array}$ & $\begin{array}{l}6.429^{* *} \\
(3.203)\end{array}$ & $\begin{array}{l}4.818^{\star *} \\
(2.344)\end{array}$ \\
\hline $\begin{array}{l}\text { Public investment }{ }^{*} \\
\text { Ins. quality }\end{array}$ & $\begin{array}{c}-1.141^{\star * *} \\
(0.305)\end{array}$ & $\begin{array}{c}-1.128^{\star * *} \\
(0.351)\end{array}$ & $\begin{array}{c}-0.863^{\star * *} \\
(0.277)\end{array}$ & $\begin{array}{c}-0.955^{\star *} \\
(0.389)\end{array}$ & $\begin{array}{c}-1.062^{\star *} \\
(0.493)\end{array}$ & $\begin{array}{c}-0.806^{* *} \\
(0.358)\end{array}$ \\
\hline Private investment & $\begin{array}{c}0.024 \\
(0.453)\end{array}$ & $\begin{array}{c}0.097 \\
(0.612)\end{array}$ & $\begin{array}{l}-0.673 \\
(0.495)\end{array}$ & $\begin{array}{l}-0.378 \\
(0.415)\end{array}$ & $\begin{array}{l}-0.160 \\
(0.563)\end{array}$ & $\begin{array}{l}-0.755 \\
(0.475)\end{array}$ \\
\hline
\end{tabular}




\section{Continued}

\begin{tabular}{ccccccc}
\hline \multirow{2}{*}{ Recurrent expenditure } & $-9.174^{* * *}$ & $-8.547^{* * *}$ & $-11.766^{* * *}$ & $-8.439^{* *}$ & $-8.885^{*}$ & $-9.138^{* *}$ \\
& $(2.600)$ & $(3.178)$ & $(3.545)$ & $(3.828)$ & $(4.739)$ & $(4.350)$ \\
Labor force & $8.455^{* * *}$ & $10.831^{* * *}$ & $11.667^{* * *}$ & $9.508^{* * *}$ & $12.422^{* * *}$ & $12.904^{* * *}$ \\
& $(2.232)$ & $(3.063)$ & $(2.904)$ & $(2.736)$ & $(4.617)$ & $(3.781)$ \\
Consumer price index & $-1.298^{* * *}$ & $-0.987^{* *}$ & $-1.546^{* * *}$ & $-1.370^{* *}$ & $-1.305^{*}$ & $-1.395^{* *}$ \\
& $(0.377)$ & $(0.465)$ & $(0.528)$ & $(0.560)$ & $(0.694)$ & $(0.642)$ \\
Infrastructure & & -0.328 & -0.131 & & -0.303 & -0.020 \\
Trade openness & & $(0.230)$ & $(0.177)$ & & $(0.329)$ & $(0.279)$ \\
Instrument & 19 & 19 & 19 & 19 & & -0.025 \\
Province/Observation & $52 / 260$ & $52 / 260$ & $52 / 260$ & $52 / 260$ & $52 / 260$ & $52 / 260$ \\
Sargan test & 0.900 & 0.986 & 0.923 & 0.900 & 0.986 & 0.923 \\
Hansen test & 0.853 & 0.970 & 0.737 & NA & NA & NA \\
AR (2) test & 0.343 & 0.652 & 0.887 & 0.311 & 0.735 & 0.726 \\
\hline
\end{tabular}

Note: ${ }^{* *},{ }^{* *}$ and ${ }^{*}$ denote significance at 1 percent, 5 percent and 10 percent respectively. Source: State software.

model. The results show sign, size and significance of estimated coefficients, specially the coefficients of public investment, institutional quality and their interaction term are nearly unchanged. In particular, the signs of estimated coefficients, which show the effects of public investment and labor force on economic growth, are opposite to those of correlation coefficients given in Table 2. It implies that there exists an endogenous phenomenon between the regress and and regressors. Therefore, D-GMM with instrumental variables seems to be appropriate for this empirical model.

In the estimation procedure, we detect trade openness is endogenous, so we use the lags of trade openness as instrumented and the remaining variables (economic growth, public investment, institutional quality, private investment, recurrent expenditure, labor force, infrastructure, and consumer price index) as instruments. In order to assess the validity of these instruments and the serial auto-correlation of residuals, we performs the Sargan and Hansen tests (test of over-identifying restrictions with the null hypothesis "the instruments as a group are exogenous") as well as the Arellano-Bond test for serial correlation AR (2), which is applied to the difference residuals to purge the unobserved and perfectly auto-correlated. In Table 3 the Hansen and Sargan tests for over-identifying restrictions indicate that the instrument set turns out valid. The Arellano-Bond AR (2) tests accept the hypothesis of no autocorrelation of the second order. These results support our model specification.

The estimated results presented in the Table 3 show that: 1) the first lag of growth correlates significantly and negatively with GDP growth rate, confirming the conditional convergence of per capita income among provinces in the long term [35] [36]; 2) public investment and institutional quality have positive ef- 
fects on economic growth, but their interaction term has a negative influence on it; 3) recurrent expenditure and consumer price index have significantly negative effects while labor force has a significantly positive impact on economic growth.

Public investment enhances economic growth. This result is obviously consistent with [6] [7] [12] [13] [14] [16] [17] [18]. In recent years public capital expenditure in provinces of Vietnam is largely invested in infrastructure development to serve for local economic activities, in building schools to improve quality of education, and in building hospitals to improve the quality of healthcare. Thus, in Vietnam public investment positively contributes to economic growth through providing infrastructure for economic activities and enhances accumulation of human capital through education and health.

Similarly, institutional quality improves economic growth. [23] [47]-[53] confirm that the hypothesis institutional quality significantly and positively contributes to economic growth. [54] show institutions are fundamental causes of long-term growth. Noticeably, [54] argue that differences in institutional quality among countries lead to cross-country differences in per capita income and in level of development.

Contrary to public investment and institutional quality, their interaction term impedes economic growth. Indeed, in Vietnam some public investment projects have poor quality and do not meet people's demand. To reduce such projects, the Vietnam government continuously improves institutional quality to ensure the supervision of people and the effectiveness of public investment projects. It also means limiting corruption or improving institutional quality in public investment projects. [4] [9] [55] provide empirical evidence to show a decrease in corruption or an improvement in public governance may reduce public investment. As a result, the interaction term between institutional quality and public investment may have a significantly negative contribution to economic growth.

The public recurrent expenditure, a nonproductive expenditure, is basically local government spending on administration such as wages, salaries, interest on loans, maintenance cost... which does not result in the creation or acquisition of fixed assets. [56] indicate the negative but insignificant impact of recurrent expenditure on economic growth. Thus, in this paper its impact on economic growth is significantly negative.

In the economic growth models, labor force is one of two major inputs to promote the output. It is also an endogenous variable. [57] [58] empirically demonstrate labor force has a positive impact on growth. Meanwhile, [30] argue that consumer price index (proxy for inflation) is detrimental to the economy because it increases the transaction costs of economic activities. This study supports this argument. [59] [60] previously confirm the negative impact of inflation on economic growth.

Table 4 reports the estimates of the public investment-growth relationship under different institutional environments. The effects of control variables such as labor force and consumer price index on economic growth are highly consistent with those in Table 3. However, there is a difference in the effect of public 
Table 4. Public investment and growth: D-GMM, 2005-2014. Dependent variable: $\Delta$ Real GDP per capita.

\begin{tabular}{|c|c|c|c|c|}
\hline \multirow{3}{*}{ Variables } & \multicolumn{2}{|c|}{ Good institutional environment } & \multicolumn{2}{|c|}{ Poor institutional environment } \\
\hline & Two-step & One-step & Two-step & One-step \\
\hline & D-GMM & D-GMM & D-GMM & D-GMM \\
\hline Real GDP per capita $(-1)$ & $\begin{array}{c}-0.800^{* * *} \\
(0.076)\end{array}$ & $\begin{array}{c}-0.798^{* * *} \\
(0.089)\end{array}$ & $\begin{array}{c}-0.716^{* * *} \\
(0.103)\end{array}$ & $\begin{array}{c}-0.658^{* * *} \\
(0.151)\end{array}$ \\
\hline Public investment & $\begin{array}{l}1.020^{* *} \\
(0.412)\end{array}$ & $\begin{array}{l}1.524^{* *} \\
(0.715)\end{array}$ & $\begin{array}{c}-2.265^{* * *} \\
(0.835)\end{array}$ & $\begin{array}{c}-2.589^{* * *} \\
(0.864)\end{array}$ \\
\hline Private investment & $\begin{array}{c}0.466 \\
(0.194)\end{array}$ & $\begin{array}{c}0.767 \\
(0.228)\end{array}$ & $\begin{array}{c}0.601 \\
(0.159)\end{array}$ & $\begin{array}{c}0.552 \\
(0.216)\end{array}$ \\
\hline Recurrent expenditure & $\begin{array}{c}-6.655^{\star * *} \\
(1.102)\end{array}$ & $\begin{array}{c}-8.968^{* * *} \\
(2.155)\end{array}$ & $\begin{array}{l}-0.754 \\
(0.843)\end{array}$ & $\begin{array}{l}-0.048 \\
(1.023)\end{array}$ \\
\hline Labor force & $\begin{array}{c}7.577^{* * *} \\
(0.964)\end{array}$ & $\begin{array}{c}8.161^{\star * \star} \\
(1.547)\end{array}$ & $\begin{array}{c}1.873^{\star * *} \\
(0.378)\end{array}$ & $\begin{array}{c}1.795^{\star * *} \\
(0.473)\end{array}$ \\
\hline Consumer price index & $\begin{array}{c}-0.538^{* * *} \\
(0.114)\end{array}$ & $\begin{array}{c}-0.896^{* * *} \\
(0.282)\end{array}$ & $\begin{array}{c}-0.439^{* * *} \\
(0.106)\end{array}$ & $\begin{array}{c}-0.324^{* *} \\
(0.154)\end{array}$ \\
\hline Infrastructure & $\begin{array}{l}-0.011 \\
(0.011)\end{array}$ & $\begin{array}{l}-0.003 \\
(0.023)\end{array}$ & $\begin{array}{c}0.052 \\
(0.028)\end{array}$ & $\begin{array}{c}0.017 \\
(0.034)\end{array}$ \\
\hline Trade openness & $\begin{array}{c}0.011 \\
(0.013)\end{array}$ & $\begin{array}{c}-0.0008 \\
(0.016)\end{array}$ & $\begin{array}{c}0.141 \\
(0.075)\end{array}$ & $\begin{array}{c}0.163 \\
(0.084)\end{array}$ \\
\hline Instrument & 23 & 20 & 14 & 14 \\
\hline Province/Observation & $48 / 253$ & $48 / 253$ & $41 / 163$ & $41 / 163$ \\
\hline Sargan test & 0.104 & 0.344 & 0.130 & 0.130 \\
\hline Hansen test & 0.178 & NA & 0.248 & NA \\
\hline $\mathrm{AR}(2)$ test & 0.982 & 0.779 & 0.820 & 0.755 \\
\hline
\end{tabular}

Note: ${ }^{* *},{ }^{* *}$ and ${ }^{\star}$ denote significance at 1 percent, 5 percent and 10 percent respectively. Source: State software.

investment on economic growth between good and poor institutional environment. This relationship is positive under good institutional environment and negative under poor one. It implies that under bad institutional environment, public capital spending may be detrimental to the economy because the design of policies does not take account of crowding-out effect of public sector on private sector as well as can not strictly monitor and supervise the efficiency and rationality of public investment projects. On the contrary, under good institutional environment, the design and promulgation process of policies related to public capital spending eliminates the crowding-out impact of public investment (instead improving the crowding-in of public investment), builds the criteria and rules to make sure the efficiency and rationality of public investment projects, and sets up the mechanisms to effectively monitor and supervise these projects. Thus, public capital spending promotes economic growth.

In short, the institutional quality plays a crucial role in the public investmentgrowth relationship. In particular, the interaction term between public invest- 
ment and institutional quality is negative while public investment enhances economic growth only under a good institutional environment. These estimates seem not to contradict. It implies there exists a threshold value of institutional quality at which the public investment-growth relationship will change (In this study, the threshold value of institutional quality is $\gamma=57$ points). This threshold value divides the institutional environment into good one and poor one. In case the poor institutional environment is prominent, as the case of Vietnam in our study, an increase in institutional quality do not improve the efficiency of public investment projects, and consequently impedes economic growth.

\subsection{Robustness Check}

To check the robustness of the estimation, we re-estimate Equation (8), Equation (11), and Equation (12) using the one step D-GMM. The corresponding results are reported in Table 3 and Table 4. Consistent with the two step D-GMM estimates, we find public investment and institutional quality promote economic growth, but their interaction term reduces it (Table 3). Similarly, the public investment-growth relationship is positive under good institutional environment and negative under poor one (Table 4). These findings are confirmed by battery of diagnostic tests shown at the bottom of Table 3 and Table 4 (Sargan and Arellano-Bond AR (2) tests), indicating that our one step D-GMM estimates are largely reliable.

\section{Conclusions and Policy Implications}

As an emerging economy with a relatively high level of public investment, Vietnam is trying to reform the institutional environment and policies to enhance economic growth. Does the institutional environment affect the public investment-growth relationship in Vietnam? We find the answer by using the two-step D-GMM for a balanced panel data of 52 provinces during the period 2005-2014. Then, we examine the public investment-growth relationship under different institutional environments. The contribution of the paper is to test whether the public investment-growth relationship depends on the quality of institutional environment. Therefore, the empirical results not only contribute to our understanding of the role of institutional quality in the public investment-growth relationship, but also suggest some important policy implications to the governments in developing countries, especially the Vietnam government.

In line with previous literature, our study indicates public investment and institutional quality boost economic growth, but their interaction term impedes growth rate. In particular, the empirical results confirm the dependence of the public investment-growth relationship on the quality of institutional environment. This relationship is positive under the good institutional environment and negative under poor one. From these findings, we emphasize that any research on the public investment-growth relationship in Vietnam without taking the role of institutional environment into account is likely to be a shortcoming. 
The findings provide a case for more prudence in design, formulation and implementation of policies relating to public investment in developing countries. The implication is that the institutional environment plays a crucial role in the public investment-growth relationship, and moreover, the good one not only promotes economic growth but sets up a helpful effect on this dynamic relationship as well. Therefore, governments in developing countries, especially the Vietnam government, should strongly implement institutional reforms to provide a conducive environment for contribution of public capital and enhancing economic growth. For future research, it will be useful to look at the effect of different public capital spending by sector on economic growth under different institutional environments.

\section{Conflicts of Interest}

The author declares no conflicts of interest regarding the publication of this paper.

\section{References}

[1] Haughwout, A.F. (2002) Public Infrastructure Investments, Productivity and Welfare in Fixed Geographic Areas. Journal of Public Economics, 83, 405-428. https://doi.org/10.1016/S0047-2727(00)00164-X

[2] Egger, H. and Falkinger, J. (2006) The Role of Public Infrastructure and Subsidies For Firm Location and International Outsourcing. European Economic Review, 50, 1993-2015. https://doi.org/10.1016/j.euroecorev.2005.10.002

[3] Aschauer, D.A. (1989) Does Public Capital Crowd Out Private Capital? Journal of Monetary Economics, 24, 171-188.

[4] Haque, M.E. and Kneller, R. (2015) Why Does Public Investment Fail to Raise Economic Growth? The Role of Corruption. The Manchester School, 83, 623-651. https://doi.org/10.1111/manc. 12068

[5] Tanzi, V. and Davoodi, H. (1998) Corruption, Public Investment, and Growth. Springer, Japan.

[6] Rodríguez-Pose, A., Psycharis, Y. and Tselios, V. (2012) Public Investment and Regional Growth and Convergence: Evidence from Greece. Papers in Regional Science, 91, 543-568. https://doi.org/10.1111/j.1435-5957.2012.00444.x

[7] Abiad, M.A., Furceri, D. and Topalova, P. (2016) The Macroeconomic Effects of Public Investment: Evidence from Advanced Economies. Journal of Macroeconomics, 50, 224-240. https://doi.org/10.1016/j.jmacro.2016.07.005

[8] Andrade, J.S. and Duarte, A.P. (2016) Crowding-In and Crowding-Out Effects of Public Investments in the Portuguese Economy. International Review of Applied Economics, 30, 488-506. https://doi.org/10.1080/02692171.2015.1122746

[9] Grigoli, F. and Mills, Z. (2014) Institutions and Public Investment: An Empirical Analysis. Economics of Governance, 15, 131-153. https://doi.org/10.1007/s10101-013-0137-y

[10] Xu, Y. and Yao, Y. (2015) Informal Institutions, Collective Action, and Public Investment in Rural China. American Political Science Review, 109, 371-391.

[11] De la Croix, D. and Delavallade, C. (2009) Growth, Public Investment and Corruption with Failing Institutions. Economics of Governance, 10, 187-219. 
https://doi.org/10.1007/s10101-008-0057-4

[12] Khan, Y., Tariq, M. and Sasaki, K. (2001) Roles of Public Capital in Pakistan's Economy: Productivity, Investment and Growth Analysis. Review of Urban and Regional Development Studies, 13, 143-162. https://doi.org/10.1111/1467-940X.00037

[13] Mittnik, S. and Neumann, T. (2001) Dynamic Effects of Public Investment: Vector Autoregressive Evidence from Six Industrialized Countries. Empirical Economics, 26, 429-446. https://doi.org/10.1007/s001810000064

[14] Milbourne, R., Otto, G. and Voss, G. (2003) Public Investment and Economic Growth. Applied Economics, 35, 527-540. https://doi.org/10.1080/0003684022000015883

[15] Murty, K.N. and Soumya, A. (2007) Effects of Public Investment on Growth and Poverty. Economic and Political Weekly, 42, 47-59.

[16] Kataoka, M. (2005) Effect of Public Investment on the Regional Economies in Postwar Japan. Review of Urban and Regional Development Studies, 17, 115-139. https://doi.org/10.1111/j.1467-940X.2005.00100.x

[17] Ramirez, M.D. and Nazmi, N. (2003) Public Investment and Economic Growth in Latin America: An Empirical Test. Review of Development Economics, 7, 115-126. https://doi.org/10.1111/1467-9361.00179

[18] Belloc, M. and Vertova, P. (2006) Public Investment and Economic Performance in Highly Indebted Poor Countries: An Empirical Assessment. International Review of Applied Economics, 20, 151-170. https://doi.org/10.1080/02692170600581086

[19] Romer, P.M. (1986) Increasing Returns and Long-Run Growth. The Journal of Political Economy, 94, 1002-1037. https://doi.org/10.1086/261420

[20] Lucas Jr., R.E. (1988) On the Mechanics of Economic Development. Journal of Monetary Economics, 22, 3-42. https://doi.org/10.1016/0304-3932(88)90168-7

[21] Blankenau, W.F. and Simpson, N.B. (2004) Public Education Expenditures and Growth. Journal of Development Economics, 73, 583-605.

https://doi.org/10.1016/j.jdeveco.2003.05.004

[22] Vieira, F., MacDonald, R. and Damasceno, A. (2012) The Role of Institutions in Cross-Section Income and Panel Data Growth Models: A Deeper Investigation on the Weakness and Proliferation of Instruments. Journal of Comparative Economics, 40, 127-140. https://doi.org/10.1016/j.jce.2011.09.004

[23] Siddiqui, D.A. and Ahmed, Q.M. (2013) The Effect of Institutions on Economic Growth: A Global Analysis Based on GMM Dynamic Panel Estimation. Structural Change and Economic Dynamics, 24, 18-33.

https://doi.org/10.1016/j.strueco.2012.12.001

[24] Aparicio, S., Urbano, D. and Audretsch, D. (2016) Institutional Factors, Opportunity Entrepreneurship and Economic Growth: Panel Data Evidence. Technological Forecasting and Social Change, 102, 45-61. https://doi.org/10.1016/j.techfore.2015.04.006

[25] Acemoglu, D., Johnson, S. and Robinson, J.A. (2005) Institutions as a Fundamental Cause of Long-Run Growth. In: Aghion, P. and Durlauf, S., Eds., Handbook of Economic Growth, Elsevier B.V., Amsterdam, 385-472. https://doi.org/10.1016/S1574-0684(05)01006-3

[26] Bose, N., Haque, M.E. and Osborn, D.R. (2007) Public Expenditure and Economic Growth: A Disaggregated Analysis for Developing Countries. The Manchester School, 75, 533-556. https://doi.org/10.1111/j.1467-9957.2007.01028.x

[27] Grossman, G.M. and Helpman, E. (1991) Trade, Knowledge Spillovers, and Growth. 
European Economic Review, 35, 517-526. https://doi.org/10.1016/0014-2921(91)90153-A

[28] Barro, R.J. and Sala-I-Martin, X. (2004) Economic Growth. 2nd Edition, The MIT Press, Cambridge, MA.

[29] Friedman, M. (1977) Nobel Lecture: Inflation and Unemployment. Journal of Political Economy, 85, 451-472. https://doi.org/10.1086/260579

[30] Jin, J. and Zou, H. (2005) Fiscal Decentralization, Revenue and Expenditure Assignments, and Growth in China. Journal of Asian Economics, 16, 1047-1064. https://doi.org/10.1016/j.asieco.2005.10.006

[31] Du, J., Lu, Y. and Tao, Z. (2008) Economic Institutions and FDI Location Choice: Evidence from US Multinationals in China. Journal of Comparative Economics, 36, 412-429. https://doi.org/10.1016/j.jce.2008.04.004

[32] Kuzmina, O., Volchkova, N. and Zueva, T. (2014) Foreign Direct Investment and Governance Quality in Russia. Journal of Comparative Economics, 42, 874-891. https://doi.org/10.1016/j.jce.2014.08.001

[33] Bissoon, O. (2012) Can Better Institutions Attract More Foreign Direct Investment (FDI)? Evidence from Developing Countries. International Research Journal of Finance and Economics, 82, 142-158.

[34] Asiedu, E. (2002) On the Determinants of Foreign Direct Investment to Developing Countries: Is Africa different? World development, 30, 107-119. https://doi.org/10.1016/S0305-750X(01)00100-0

[35] Barro, R.J., Sala-I-Martin, X., Blanchard, O.J. and Hall, R.E. (1991) Convergence across States and Regions. Brookings Papers on Economic Activity, 1991, 107-182. https://doi.org/10.2307/2534639

[36] Tondl, G. (2001) Convergence after Divergence? Regional Growth in Europe. Springer-Verlag Wien, New York.

[37] Arellano, M. and Bond, S. (1991) Some Tests of Specification for Panel Data: Monte Carlo Evidence and an Application to Employment Equations. The Review of Economic Studies, 58, 277-297. https://doi.org/10.2307/2297968

[38] Holtz-Eakin, D., Newey, W. and Rosen, H.S. (1998) Estimating Vector Autoregressions with Panel Data. Econometrica: Journal of the Econometric Society, 56, 1371-1395.

[39] Judson, R.A. and Owen, A.L. (1999) Estimating Dynamic Panel Data Models: A Guide for Macroeconomists. Economics Letters, 65, 9-15. https://doi.org/10.1016/S0165-1765(99)00130-5

[40] Roodman, D. (2006) How to do Xtabond2: An Introduction to Difference and System GMM in Stata. The Stata Journal, 9, 86-136. https://doi.org/10.2139/ssrn.982943

[41] VCCI and USAID (2015). http://eng.pcivietnam.org/bang-xep-hang

[42] Tran, T.B., Grafton, R.Q. and Kompas, T. (2008) Institutions Matter: The Case of Vietnam. The Journal of Socio-Economics, 38, 1-12.

[43] Malesky, E. and Taussig, M. (2009) Out of the Gray: The Impact of Provincial Institutions on Business Formalization in Vietnam. Journal of East Asian Studies, 9, 249-290. https://doi.org/10.1017/S1598240800003003

[44] Nguyen, T.T. and Van Dijk, M.A. (2012) Corruption, Growth, and Governance: Private vs. State-Owned Firms in Vietnam. Journal of Banking and Finance, 36, 2935-2948. https://doi.org/10.1016/j.jbankfin.2012.03.027

[45] Dang, D.A. (2013) How Foreign Direct Investment Promote Institutional Quality: 
Evidence from Vietnam. Journal of Comparative Economics, 41, 1054-1072. https://doi.org/10.1016/j.jce.2013.05.010

[46] Malesky, E., McCulloch, N. and Nhat, N.D. (2015) The Impact of Governance and Transparency on Firm Investment in Vietnam. Economics of Transition and Institutional Change, 23, 677-715. https://doi.org/10.1111/ecot.12068

[47] Ali, A.M. (2003) Institutional Differences as Sources of Growth Differences. Atlantic Economic Journal, 31, 348-362. https://doi.org/10.1007/BF02298493

[48] Law, S.H. and Bany-Ariffin, A.N. (2008) Institutional Infrastructure and Economic Performance: Dynamic Panel Data Evidence. Transition Studies Review, 15, 542-557. https://doi.org/10.1007/s11300-008-0026-1

[49] Kandil, M. (2009) Determinants of Institutional Quality and Their Impact on Economic Growth in the MENA Region. International Journal of Development Issues 8, 134-167. https://doi.org/10.1108/14468950910997693

[50] Nakabashi, L., Pereira, A.E.G. and Sachsida, A. (2013) Institutions and Growth: A Developing Country Case Study. Journal of Economic Studies, 40, 614-634. https://doi.org/10.1108/JES-09-2011-0111

[51] Azam, M. and Emirullah, C. (2014) The Role of Governance in Economic Development: Evidence from Some Selected Countries in Asia and the Pacific. International Journal of Social Economics, 41, 1265-1278. https://doi.org/10.1108/IJSE-11-2013-0262

[52] Fayissa, B. and Gill, F. (2015) Revisiting the Growth-Governance Relationship in Developing Asian and Oceanic Economies. Journal of Economics and Finance, 40, 803-816.

[53] Slesman, L., Baharumshah, A.Z. and Ra'ees, W. (2015) Institutional Infrastructure and Economic Growth in Member Countries of the Organization of Islamic Cooperation (OIC). Economic Modelling, 51, 214-226.

https://doi.org/10.1016/j.econmod.2015.08.008

[54] Acemoglu, D. and Robinson, J.A. (2013) Why Nations Fail: The Origins of Power, Prosperity, and Poverty. Crown Business, New York.

[55] Keefer, P. and Knack, S. (2007) Boondoggles, Rent-Seeking, and Political Checks and Balances: Public Investment under Unaccountable Governments. The Review of Economics and Statistics, 89, 566-572. https://doi.org/10.1162/rest.89.3.566

[56] Bleaney, M., Gemmell, N. and Kneller, R. (2001) Testing the Endogenous Growth Model: Public Expenditure, Taxation, and Growth over the Long Run. Canadian Journal of Economics, 34, 36-57. https://doi.org/10.1111/0008-4085.00061

[57] Denton, F.T. and Spencer, B.G. (1997) Population, Labour Force and Long-Term Economic Growth. Hamilton, Ont. Research Institute for Quantitative Studies in Economics and Population, McMaster University.

[58] Shahid, M. (2014) Impact of Labour Force Participation on Economic Growth in Pakistan. Journal of Economics and Sustainable Development, 5, 89-93.

[59] Bittencourt, M. (2012) Inflation and Economic Growth in Latin America: Some Panel Time-Series Evidence. Economic Modelling, 29, 333-340. https://doi.org/10.1016/j.econmod.2011.10.018

[60] Bittencourt, M., Eyden, R. and Seleteng, M. (2015) Inflation and Economic Growth: Evidence from the Southern African Development Community. South African Journal of Economics, 83, 411-424. https://doi.org/10.1111/saje.12075 